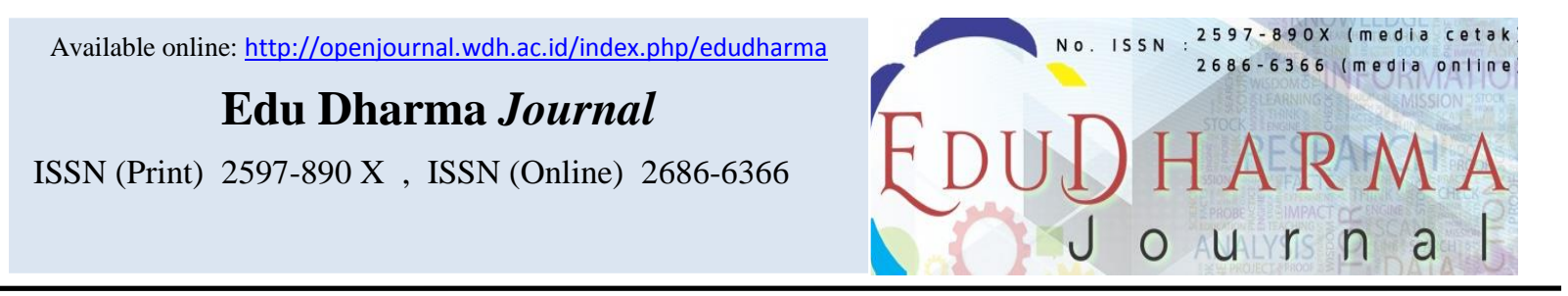

\title{
PENGARUH SENAM ERGONOMIS TERHADAP TEKANAN DARAH PRALANSIA (45-59 TAHUN) DENGAN HIPERTENSI DI WILAYAH PUSKESMAS PISANGAN
}

\author{
Veri $^{1 *}$ Tuti Amelia ${ }^{2}$ \\ ${ }^{1}$ STIKes Widya Dharma Husada ,Jalan Pajajaran No.1 Pamulang 15417, Indonesia \\ ${ }^{2}$ Mahasiswa STIKes Widya Dharma Husada ,Jalan Pajajaran No.1 Pamulang 15417, Indonesia
}

\begin{tabular}{|c|c|}
\hline ARTICLE INFORMATION & $A B S T R A C T$ \\
\hline $\begin{array}{l}\text { *Corresponding Author } \\
\text { Name : Veri } \\
\text { E-mail: stefenveri060991@ gmail.com }\end{array}$ & $\begin{array}{l}\text { Based on data from Riskesdas in 2013, the prevalence of } \\
\text { hypertension in Indonesia with age } 45 \text { to } 54 \text { years is } 35,6 \% \text { age } \\
\text { group } 55 \text { to } 64 \text { years old } 45,9 \% \text { age group } 65 \text { to } 74 \text { year equal to } \\
57,6 \% \text { and group age above } 75 \text { years } 63.8 \% \text { hypertension, uric } \\
\text { acid disease, rheumatism, diabetes miletus, is the most common }\end{array}$ \\
\hline $\begin{array}{l}\text { Keywords: } \\
\text { Hypertension_1 } \\
\text { Pre Elderly_2 } \\
\text { Ergonomic Gymnastic_3 }\end{array}$ & $\begin{array}{l}\text { According to the Ministry of Youth and Sports of the Republic of } \\
\text { Indonesia, } 2010 \text { in Puspa, } 2016 \text { Gymnastics is highly } \\
\text { recommended for those entering the age of prism (45 years) and } \\
\text { aged elderly ( } 65 \text { years and above). Some of the exercises that } \\
\text { can be done by elderly who are tera gymnastics, yoga, } \\
\text { gymnastics kagel, and ergonomic gymnastics. The purpose of } \\
\text { this study was to determine the effect of ergonomic gymnastics } \\
\text { on blood pressure on pralansia with hypertension in Puskesmas } \\
\text { Ciputat Timur Area Health Center. This study used the Pre- } \\
\text { experimental The analysis in this study used Wilcoxon statistical } \\
\text { test. The results of the study using the Wilcoxon test showed } \\
\text { Pvalue = } 0.000 \text {, and a decrease in systolic blood pressure during } \\
\text { the week of } 17.36 \text { mmHg and diastolic } 11.17 \text { mmHg. So the } \\
\text { conclusion is ergonomic gymnastics affect the decrease in blood } \\
\text { pressure in pralansia with hypertension. This research is } \\
\text { expected to be a consideration for Puskesmas Ciputat Timur } \\
\text { Pusangan to make ergonomic gymnastics as hypertension } \\
\text { control program. }\end{array}$ \\
\hline $\begin{array}{l}\text { Kata Kunci: } \\
\text { Hipertensi_1 } \\
\text { Pralansia_2 } \\
\text { Senam ergonomi_3 }\end{array}$ & $\begin{array}{l}\text { A B S T R A K } \\
\text { Berdasarkan Riskesdas tahun 2013, kejadian hipertensi di } \\
\text { Indonesia dengan umur } 45 \text { hingga } 54 \text { tahun yaitu } 35,6 \% \\
\text { kelompok usia } 55 \text { hingga } 64 \text { tahun yaitu } 45,9 \% \text { kelompok usia } \\
65 \text { hingga } 74 \text { tahun sebesar } 57,6 \% \text { dan kelompok usia diatas } 75 \\
\text { tahun yaitu 63,8\% hipertensi, penyakit asam urat, rematik, } \\
\text { diabetes miletus, merupakan keluhan kesehatan yang paling } \\
\text { tertinggi terjadi pada lansia yaitu sebesar } 32,99 \% \text {. Puspa, } 2016 \\
\text { Senam untuk mereka yang berusia pralansia (45th) dan usia } \\
\text { lansia (> 65th). Diantaranya senam lansia yaitu senam kagel, dan } \\
\text { senam ergonomis. Tujuan penelitian ini adalah untuk mengetahui }\end{array}$ \\
\hline
\end{tabular}




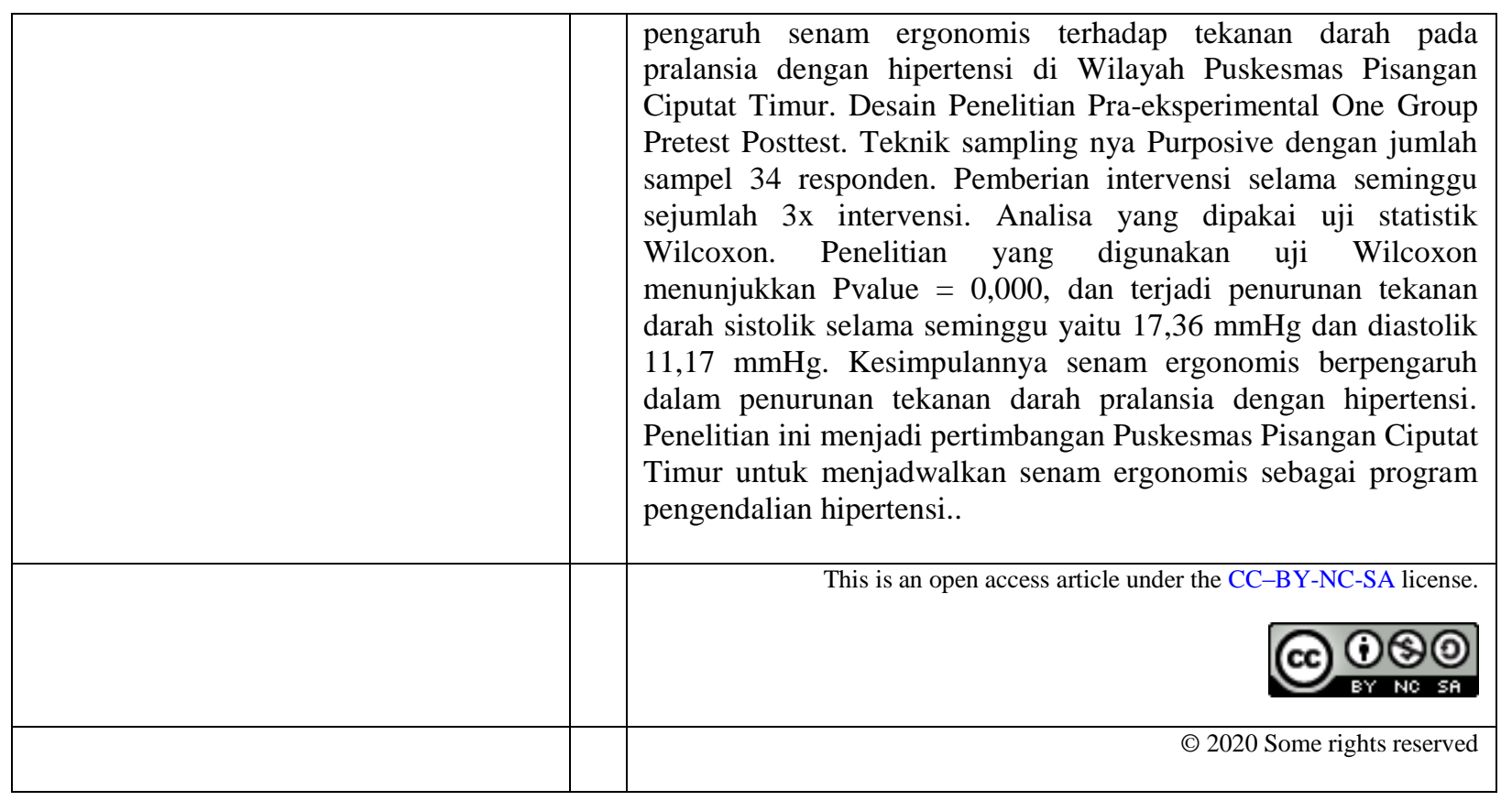




\section{PENDAHULUAN}

\section{A. Latar Belakang}

Penyakit jantung dan pembuluh darah (kardiovaskuler) adalah masalah kesehatan yang pertama di negara maju dan negara berkembang. Hipertensi menjadi penyebab kematian nomor satu di dunia setiap tahunnya. Hipertensi adalah salah satu penyakit kardiovaskular yang paling umum dan paling banyak diderita masyarakat (Depkes, 2019).

Senam ergonomik merupakan salah satu teknik senam yang memiliki gerakan yang terilhami dari gerakan sholat dan sesuai dengan kaidah penciptaan tubuh sehingga senam ini efektif logis dan efisien untuk dilakukan. Senam ini bisa membantu mengembalikan letak dan keelastisan sistem syaraf dan aliran darah, mengoptimalkan aliran darah yang masuk ke otak dan berbagai manfaat lainnya.Senam ergonomik bisa menurunkan penyempitan dan tekanan pembuluh darah, selain itu senam ini juga meningkatkan fungsi pelebaran pembuluh darah dan mengurangi resistensi pembuluh darah perifer. Elastisitas pembuluh darah meningkat dapat memudahkan pembuluh darah untuk meregang dengan cepat selama jantung memompa darah (Erliana, 2013 dalam Rizki, 2017).

\section{Menurut World Health Organization} (WHO) lansia ialah kelompok masyarakat berumur 60 tahun atau lebih. Secara mendunia tahun 2013 rerata dari populasi penduduk berusia $>60$ tahun $11,7 \%$ dari total populasi dunia dan jumlah akan meningkat sejalan peningkatan usia harapan hidup. Rerata lansia di Indonesia bertambah setiap tahunnya. Data WHO tahun 2009 lansia berjumlah 7,49\% dari total populasi, pada tahun 2013 rerata lansia sebanyak $8,1 \%$ dari populasi (WHO, 2015 dalam Febrina 2016).

Perkembangan IPTEK serta perbaikan sosial ekonomi berpengaruh pada peningkatan derajat kesehatan masyarakat dan usia harapan hidup, sehingga jumlah lansia meningkat. Peningkatan jumlah lansia berdampak pada berbagai kehidupan. Dampak utama peningkatan lansia ini adalah peningkatan ketergantungan lansia.

Menua ialah kondisi wajar dan tidak dapat dihindari pada fase kehidupan. (Amalia, 2014 dalam Kumianto 2015).

Menurut Khomarun pada tahun 2013 dalam Priadi Pada tahun 2016 etiologi hipertensi Elastisitas pembuluh darah menghilang karena tidak efektif 
pembuluh darah perifer untuk oksigenasi. (Padila, 2013)

Depkes RI tahun 2014, peringkat pertama hipertensi oleh Bangka Belitung 30,9\%, peringkat kedua Kalimantan Timur 29,\%, disusul oleh Jawa Barat 29,4\%, provinsi Banten 23,0\% dan DKI Jakarta presentasinya 20,0\%. Prevalensi hipertensi di Indonesia dengan usia 45 hingga 54 tahun 35,6\% kelompok usia 55 hingga 64 tahun sebesar 45,9\% kelompok usia 65 hingga 74 tahun $57,6 \%$ dan kelompok usia diatas 75 tahun 63,8\% hipertensi, penyakit asam urat, rematik, diabetes miletus, merupakan keluhan kesehatan yang paling tertinggi terjadi pada lansia yaitu sebesar 32,99\%. (Riskesdas, 2013).

\section{METODE PENELITIAN}

Penelitian kuantitatif dengan desain penelitian quasi eksperimen design dengan one group pretest-postest. Penelitian ini diobservasi sebanyak 2 kali sebelum dan sesudah ekperimen. pemantauan sebelum ekperimen $\left(\mathrm{O}_{1}\right)$ pre-test, dan pemantauan sesudah ekperimen $\left(\mathrm{O}_{2}\right)$ pasca-test (Arikunto, 2010).

Tempat penelitian di sekitar halaman Puskesmas Ciputat Timur yang dilaksanakan pada bulan Desember 2019 sampai Januari 2019. Penelitian ini dilakukan selama seminggu sebanyak 2 kali dalam waktu 15-25 menit, tetapi proses penyusunan penelitian iini dimulai Juli-September 2019. Populasi yang akan digunakan pada penelitian ini adalah pralansia penderita hipertensi di wilayah Puskesmas Pisangan Ciputat Timur yang berjumlah 224 orang yang diambil dari sekitar Wilayah Puskesmas Pisangan Ciputat Timur. Sampel yang diambil dalam penelitian ini adalah pralansia penderita hipertensi yang berada disekitar wilayah Puskesmas Pisangan Ciputat Timur. Pada pengambilan sampel menggunakan metode non probability (Nursalam, 2008)

Menurut Arikunto pada tahun 1998 dalam Hasan 2012 menyatakan bahwa, penentuan sampel dengan mengambil 10\%-15\% atau 20\%-25\% atau lebih jika populasi>100, <100 diambil semuanya. Karena populasi sebanyak 224 atau $>100$ maka peneliti mengambil sampel sebanyak $15 \%$

Dengan rumus Arikunto:

$$
224 \times \frac{15}{100}=33,6 .
$$

Jadi sampel yang diambil sebanyak 34 orang. Penelitian ini teknik pengambilan sampel yang digunakan adalah dengan cara Accidental yaitu pengambilan sampel yang dilakukan sesaat atau yang ada pada waktu itu (Suyanto, 2011). 
Kriteria yang digunakan:

1) Kriteria Inklusi:

a. Pralanjut usia yang penderita hipertensi tanpa minum obat

b. Klien dengan usia 45-59 tahun

c. Tinggal di wilayah Puskesmas Pisangan Ciputat Timur

d. Mampu melakukan mobilisasi

e. Bersedia bekerjasama selama penelitian

2) Kriteria Eksklusi:

a. Klien tidak hipertensi

b. Klien yang memiliki fraktur pada eksremitas atas dan eksremitas bawah

c. Klien yang berusia $<45$ dan $>59$ tahun Klien yang sedang alam kondisi pemulihan dari serangan jantung dan penyakit gagal ginjal akut

d. Klien yang memiliki riwayat pembedahan dalam waktu minimal 1 bulan

e. Klien mengalami sakit kepala

\section{HASIL PENELITIAN}

\section{ANALISIS UNIVARIAT}

\section{a. Usia}

Usia responden digolongkan menjadi sepuluh kelompok berdasarkan perhitungan dengan menggunakan rumus interval kelas pada tabel distribusi frekuensi yaitu usia 45-54 tahun, dan usia 55-59 tahun. Data tersebut disajikan pada tabel di halaman selanjutnya

\section{Diagram 1}

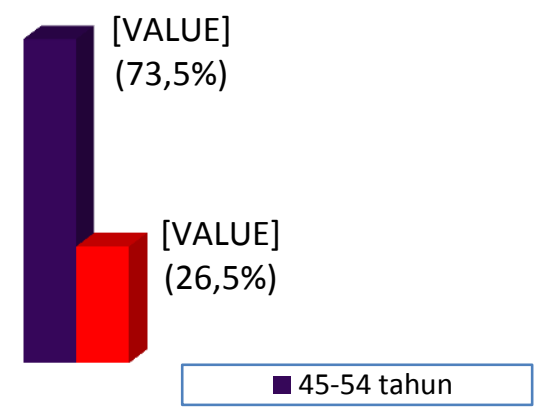

\section{b. Jenis Kelamin}

$$
\begin{array}{lr}
\text { Karakteristik } & \text { responden } \\
\text { berdasarkan jenis } & \text { kelamin } \\
\text { disajikan dalam } & \text { tabel } \\
\text { sebagai berikut } &
\end{array}
$$

Diagram 2 Distribusi Frekuensi Jenis Kelamin Responden di Wilayah Puskesmas Pisangan Ciputat Timur $(\mathrm{n}=34)$

[VALUE]

(100\%)

[VALUE]

(0\%)

Perempuan Laki-laki 
Diagram 3. Distribusi frekuensi Tekanan Darah Responden Sebelum (Pre) Diberi Perlakuan Senam Ergonomis di Wilayah Puskesmas Pisangan Ciputat Timur $(\mathrm{n}=$ 34)

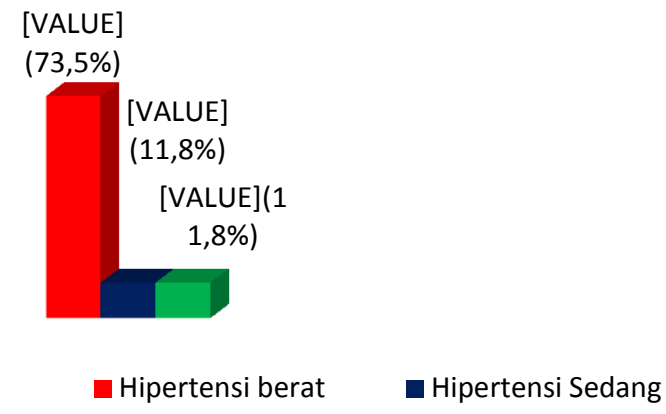

\section{c. Tekanan Darah Responden (PostTest)}

Diagram 4 . Distribusi Frekuensi Tekanan Darah Responden Sesudah (Post) Diberi Perlakuan Senam Ergonomis di Wilayah Puskesmas Pisangan Ciputat Timur ( $\mathrm{n}=$ 34)

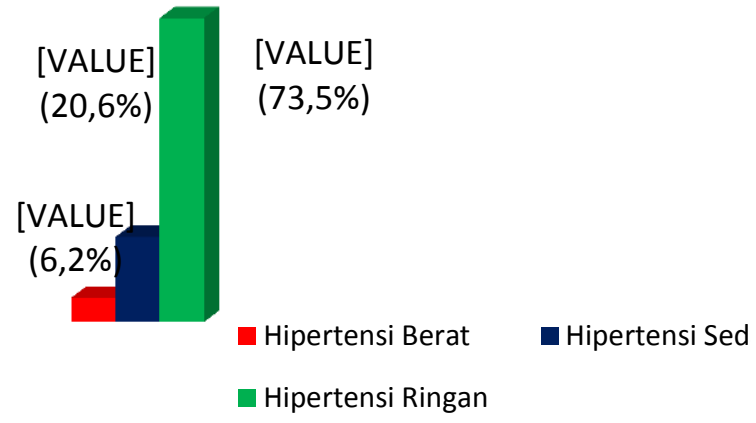

\section{Analisis Bivariat}

a. Analisis Tekanan Darah Responden Sebelum (Pre) dan Sesudah (Post) Diberi Perlakuan Senam Ergonomis $(\mathrm{n}=34)$

Tabel 1. Hasil Analisis Tekanan Darah Responden Sebelum (Pre) dan Sesudah (Post) Diberi Perlakuan Senam Ergonomis $(\mathrm{n}=34)$

\begin{tabular}{cccc}
\hline $\begin{array}{c}\text { Tekanan } \\
\text { Darah }\end{array}$ & Pre Test & Post Test & $\begin{array}{c}\text { Rata-Rata } \\
\text { Penurunan }\end{array}$ \\
\hline Sistolik & 153,24 & 135,88 & 17,36 \\
Diastolik & 95,29 & 84,12 & 11,17 \\
\hline
\end{tabular}

Tabel 2. Hasil Analisis Tekanan Darah Sebelum (Pre) dan Sesudah (Post) Diberi Perlakuan Senam Ergonomis $(n=34)$

\begin{tabular}{ccc}
\hline Tekanan Darah & $\begin{array}{c}\text { Rata-Rata } \\
\text { Penurunan }\end{array}$ & Pvalue \\
\hline Sistolik & 17,36 & 0,000 \\
Diastolik & 11,17 & \\
\hline
\end{tabular}

\section{B. PEMBAHASAN}

\section{Analisis Univariat}

Analisis Univariat pada penelitian ini meliputi jenis kelamin, usia, konsumsi obat antihipertensi, riwayat merokok, dan riwayat hipertensi keluarga

\section{a. Usia}

Dilihat dari distribusi frekuensi responden berdasarkan usia terhadap pralansia dengan hipertensi di Wilayah Puskesmas Pisangan Ciputat Timur didapatkan bahwa lebih dari setengahnya responden berusia 45-54 tahun sebanyak 25 responden $(73,5 \%)$

Hal ini sejalan dengan penelitian yang dilakukan oleh Dedullah, Molanda \& Joseph, 2015, hasil penelitian yang dilakukan peneliti yaitu kategori usia $\geq 43$ tahun memiliki resiko 5 kali lebih besar menderita hipertensi dibandingkan kategori usia $\leq 43$ tahun. 
Pada proses fisiologi terjadi peningkatan aktifitas simpatik, dinding arteri akan mengalami penebalan karena kolagen yang menumpuk pada lapisan otot, sehingga pembuluh darah berangsurangsur menjadi sempit dan kaku. Selain itu pada usia lanjut sensitivitas pengatur tekanan darah yaitu baroreseptor mulai berkurang, demikian juga dengan peran ginjal dimana aliran darah ginjal dan lanju filtrasi glomerulus menurun, hal ini memicu terjadinya hipertensi (Kurniasih \& Setiawan, 2013)

\section{b. Jenis Kelamin}

Hasil distribusi frekuensi responden berdasarkan jenis kelamin terhadap pralansia dengan hipertensi di Wilayah Puskesmas Pisangan Ciputat Timur didapatkan bahwa seluruh responden berjenis kelamin perempuan sebanyak 34 responden (100\%). Total seluruh esponden adalah 34 responden

Hal ini sejalan dengan penelitian yang dilakukan oleh Novitaningtyas, 2014. Jenis kelamin dapat mempengaruhi tekanan darah yang dapat dikaitkan dengan usia individu. Terdapat perbedaan jenis kelamin dalam hubungannya antara usia dan tekanan darah sistolik. Pria memiliki tekanan darah sistolik lebih tinggi dibandingkan perempuan selama dewasa awal dan dewasa tengah, sedangkan perempuan cenderung memiliki tingkat tekanan darah sistolik lebih tinggi setelah menopause yaitu diatas usia 45 tahun.

c. Tekanan Darah Responden Pre Test

Berdasarkan dari distribusi frekuensi responden pralansia di Wilayah Puskesmas Pisangan Timur lebih dari setengahnya mengalami hipertensi ringan sebanyak 25 responden $(73,5 \%)$

\section{d. Tekanan Darah Responden Post} Test

Diagram dan pembahasan tekanan darah responden Post Test dilakukan senam ergonomis di Wilayah Puskesmas Pisangan Ciputat Timur terdapat pada halaman selanjutnya dengan hipertensi di Wilayah Puskesmas Pisangan Ciputat Timur sesudah dilakukan intervensi senam egoonomis terjadi penurunan tekanan darah, hampir setengahnya mengalami penurunan tekanan darah menjadi normal sebanyak 11 responden $(32,4 \%)$ 


\section{ANALISIS BIVARIAT}

Berdasarkan hasil uji Wilcoxon di dapatkan nilai signifikan $($ Pvalue $)=0,000 \quad(p<0,05) \quad$ sehingga dapat disimpulkan bahwa H0 ditolak dan Ha diterima. Yaitu Ada pengaruh senam ergonomis terhadap penurunan tekanan darah pralansia di Wilayah Puskesmas Pisangan Ciputat Timur.

Berdasarkan Tabel memperlihatkan data nilai tekanan darah sistolik pre test rata-rata sebesar $153,24 \mathrm{mmHg}$, dan tekanan darah sistolik post test sebesar 135,88 mmHg. Dari data tersebut maka didapatkan rata-rata penurunan tekanan darah sistolik pre test dan post test yaitu $17,36 \mathrm{mmHg}$. Untuk tekanan darah diastolik didapatkan data pre test yaitu 95,29 $\mathrm{mmHg}$ dan post test yaitu 84,17 mmHg. Dari data tersebut maka didapatkan rata-rata penurunan tekanan darah diastolik yaitu 11,17 mmHg. Berdasarkan penjelasan diatas maka dapat dikatakan bahwa terdapat penurunan tekanan darah sistolik dan diastolik sesudah dilakukan intervensi senam ergonomis.

Hal ini sejalan dengan penelitian yang dilakukan Wratsongko, 2014, Senam ergonomis itu sendiri merupakan teknik senam dan pernapasan untuk mengembalikan atau memperbaiki posisi kelenturan sistem saraf dan aliran darah. Apabila kelenturan aliran darah baik maka akan memudahkan pembuluh darah untuk mengendur dengan cepat selama jantung memompa darah. Pada pembuluh darah yang kurang elastis atau kaku akan menyulitkan pembuluh darah kendur dengan cepat saat jantung memompa, yang nantinya akan berakibat tekanan darah lebih meningkat saat jantung berkontraksi. Senam ergonomis juga memaksimalkan suplai oksigen ke otak, apabila pembuluh darah elastis darah akan mengalir dengan mudah ke otak, sehingga otak tidak kekurangan oksigen dan nutrisi dan terihindar dari kerusakan pembuluh darah di otak. Senam ergonomis pun dapat memaksimalkan sisem pembakaran salah satunya pembakaran kolesterol. Pembakaran kolesterol akan mempengaruhi tingka LDL dalam darah dan meningkatkan HDL yang nantinya akan mengurangi aterosklerosis yang menghambat aliran darah. Gerakan yang terkandung dalam senam ergonomis merupakan rangkaian gerakan shalat yang dilakukan manusia sejak dulu sampai saat ini. 


\section{KESIMPULAN}

1. Teridentifikasi karakteristik responden berdasarkan Jenis kelamin yaitu wanita sebanyak 34 (100\%) responden, Usia responden terbanyak berusia $45-54$ tahun sebanyak 25 responden $(73,5 \%)$.

2. Teridentifikasi tekanan darah pralansia di Wilayah Puskesmas Pisangan Ciputat Timur sebelum dilakukan senam ergonomis responden dengan hipertensi berat terbanyak sebanyak 25 responden $(73,5 \%)$

3. Teridentifikasi tekanan darah pralansia di Wilayah Puskesmas Pisangan Ciputat Timur sesudah dilakukan senam lebih rendah dari tekanan darah sesudah dilakukan senam ergonomis Responden dengan tekanan darah hipertensi ringan hampir setengahnya sebanyak 25 responden $(73,5 \%)$, responden dengan tekanan darah hipertensi sedang sebagian kecil sebanyak 7 responden $(20,6 \%)$, responden dengan hipertensi berat sebagian kecil sebanyak 2 responden $(6,2 \%)$.

4. Teridentifikasi rata-rata penurunan tekanan darah pralansia setelah dilakukan senam ergonomis di wilayah Puskesmas Pisangan Ciputat Timur yaitu Sistolik 17,36 $\mathrm{mmHg}$ dan Diastolik 11,17 mmHg.
5. Dari data tersebut maka didapatkan ratarata penurunan tekanan darah sistolik pre test dan post test yaitu 17,36 mmHg. Untuk tekanan darah diastolik didapatkan data pre test yaitu 95,29 $\mathrm{mmHg}$ dan post test yaitu $84,17 \mathrm{mmHg}$. Dari data tersebut maka didapatkan ratarata penurunan Dari data tersebut maka didapatkan rata-rata penurunan tekanan darah sistolik pre test dan post test yaitu 17,36 mmHg. Untuk tekanan darah diastolik didapatkan data pre test yaitu 95,29 $\mathrm{mmHg}$ dan post test yaitu 84,17 mmHg. Dari data tersebut maka didapatkan rata-rata penurunan Dari hasil uji statistik dari ketiga hari hasil penelitian diperoleh Pvalue 0,000 < 0,05 , yang artinya terdapat pengaruh senam ergonomis terhadap tekanan darah pada pralansia dengan hipertensi di Wilayah Puskesmas Pisangan Ciputat Timur.

\section{DAFTAR PUSTAKA}

Adriyani, P. P., \& Sudhana, I. W. 2014. Prevalensi dan Faktor-Faktor Terjadinya Hipertensi pada Masyarakat di Desa Sidemen Kecamatan Sidemen Karangasem Periode Juni-Juli 2014. Diakses pada tanggal 30 Agustus 2019

Aisyah, Ayu Fita. 2011. Analisis FaktorFaktor Yang Mempengaruhi Kejadian Hipertensi Primer Di Desa Trunuh Klaten Selatan. Diakses pada tanggal 3 September 2019 
Anggara, D. H. D., \& Prayitno, N. 2013. Faktor-Faktor yang Berhilubungan dengan Tekanan Darah di Puskesmas Telaga Murni, Cikarang Barat Tahun 2012. Diakses pada tanggal 30 Agustus 2019

Arikunto. 2013. Metodologi Penelitian Kesehatan. Jakarta. Rineka Cipta.

As'adi Muhammad. 2012. Serba Serbi Gagal Ginjal. Jogjakarta. Diva press.

Aspiani Yuli. 2014. Asuhan Keperawatan Geontik. Jakarta Timur. TIM.

Dewi, Sofia Rosma. 2012. Buku Ajar Keperawatan Gerontik. Yoyakarta.

Dojo, Pascaria Christin,dkk. 2016. Hubungan Kebiasaan Merokok, Stres, Riwayat Keluarga Dengan Kejadian Hipertensi Pada Pasien Di Rumah Sakit Umum Daerah Noongan. Jakarta. Salemba Medika

Heri, dkk. 2015. Pengaruh Senam Ergonomik Terhadap Tekanan Darah Pada Pederita Hipertensi Di Desa Sumber Agung Kecamatan Jatirejo Kabupaten Mojokerto. Diakses pada tanggal 12 Oktober 2019

Khurniawan, dkk. 2017. Stetoskop Elektronik Sederhana Untuk Auskultasi Jantung Dan Paru.

Kurniadi. 2013. Stop Gejala Penyakit Jantung Koroner. Yogyakarta. Familia Pustaka Keluarga.

Martuti. 2009. Hipertensi. Yogyakarta. Arya Medika

Padila. 2013. Buku Ajar Keperawatan gerontik. Jogjakarta. Nuha Medika
Soerianata, Suryana. 2010. Mencegah Dan Mengatasi Penyakit Jantung Koroner Secara Tepat Dan Cepat. 